Biogeosciences, 10, 3931-3941, 2013

www.biogeosciences.net/10/3931/2013/

doi:10.5194/bg-10-3931-2013

(C) Author(s) 2013. CC Attribution 3.0 License.

\title{
Long-term nitrogen addition decreases carbon leaching in a nitrogen-rich forest ecosystem
}

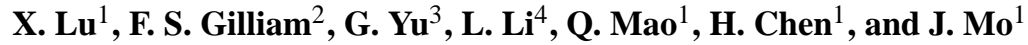 \\ ${ }^{1}$ Key Laboratory of Vegetation Restoration and Management of Degraded Ecosystems, South China Botanical Garden, \\ Chinese Academy of Sciences, Guangzhou 510650, China \\ ${ }^{2}$ Department of Biological Sciences, Marshall University, Huntington, West Virginia, 25755-2510, USA \\ ${ }^{3}$ Institute of Geographical Sciences and Natural Resources Research, Chinese Academy of Sciences, Beijing 100101, China \\ ${ }^{4}$ State Key Laboratory of Vegetation Environmental Change, Institute of Botany, Chinese Academy of Sciences, Xiangshan, \\ Beijing, 100093, China
}

Correspondence to: J. Mo (mojm@scib.ac.cn)

Received: 14 December 2012 - Published in Biogeosciences Discuss.: 29 January 2013

Revised: 18 April 2013 - Accepted: 6 May 2013 - Published: 18 June 2013

\begin{abstract}
Dissolved organic carbon (DOC) plays a critical role in the carbon $(\mathrm{C})$ cycle of forest soils, and has been recently connected with global increases in nitrogen $(\mathrm{N})$ deposition. Most studies on effects of elevated $\mathrm{N}$ deposition on DOC have been carried out in $\mathrm{N}$-limited temperate regions, with far fewer data available from $\mathrm{N}$-rich ecosystems, especially in the context of chronically elevated $\mathrm{N}$ deposition. Furthermore, mechanisms for excess $\mathrm{N}$-induced changes of DOC dynamics have been suggested to be different between the two kinds of ecosystems, because of the different ecosystem $\mathrm{N}$ status. The purpose of this study was to experimentally examine how long-term $\mathrm{N}$ addition affects DOC dynamics below the primary rooting zones (the upper $20 \mathrm{~cm}$ soils) in typically $\mathrm{N}$-rich lowland tropical forests. We have a primary assumption that long-term continuous $\mathrm{N}$ addition minimally affects DOC concentrations and effluxes in $\mathrm{N}$-rich tropical forests. Experimental $\mathrm{N}$ addition was administered at the following levels: $0,50,100$ and $150 \mathrm{~kg} \mathrm{Nha}^{-1} \mathrm{yr}^{-1}$, respectively. Results showed that seven years of $\mathrm{N}$ addition significantly decreased DOC concentrations in soil solution, and chemo-physical controls (solution acidity change and soil sorption) rather than biological controls may mainly account for the decreases, in contrast to other forests. We further found that $\mathrm{N}$ addition greatly decreased annual DOC effluxes from the primary rooting zone and increased waterextractable DOC in soils. Our results suggest that long-term $\mathrm{N}$ deposition could increase soil $\mathrm{C}$ sequestration in the upper soils by decreasing DOC efflux from that layer in $\mathrm{N}$-rich
\end{abstract}

ecosystems, a novel mechanism for continued accumulation of soil C in old-growth forests.

\section{Introduction}

Terrestrial ecosystem carbon (C) cycling and storage are a global concern in the context of increasing atmospheric deposition of $\mathrm{N}$ in the biosphere, especially in recent decades (Schindler and Bayley, 1993; Nadelhoffer et al., 1999; Galloway et al., 2004; LeBauer and Treseder, 2008; Hyvönen et al., 2008). Although it is generally known that $\mathrm{N}$ deposition can significantly alter terrestrial ecosystem $\mathrm{C}$ cycle, most studies on the responses of ecosystem $\mathrm{C}$ cycling to $\mathrm{N}$ enrichment focused on net primary productivity (NPP), net ecosystem productivity, net ecosystem $\mathrm{CO}_{2}$ exchange, and labile pools of C (LeBauer and Treseder, 2008; Hyvönen et al., 2008; de Vries et al., 2009; Liu and Greaver, 2010; Thomas et al., 2010). In contrast, effects of $\mathrm{N}$ on dissolved organic $\mathrm{C}$ (DOC) have received less attention, likely because these effluxes are small relative to the $\mathrm{C}$ fluxes associated with primary productivity or heterotrophic respiration in terrestrial systems (Kalbitz et al., 2000; Neff and Asner, 2001). However, the dynamics of DOC are receiving increased attention, considering their essential links in the bio-, hydro- and pedosphere (Kalbitz et al., 2000) and their central importance in soil-forming processes and carbon sequestration via DOC mobilization and transport for both temperate and tropical 
soils (McDowell, 1998; Monteith et al., 2007; Cusack et al., 2010; Liu and Greaver, 2010; Kindler et al., 2011).

Forest soils play a key role in the global $\mathrm{C}$ cycle (Lal, 2005). To explore the importance of DOC effluxes under elevated $\mathrm{N}$ deposition in forest ecosystems, ecologists have conducted such studies by the methods of simulating $\mathrm{N}$ deposition or using natural $\mathrm{N}$ deposition gradients (Evans et al., 2008; Sleutel et al., 2009). Until now, these studies are limited to DOC dynamics (e.g. concentrations or effluxes), and have not been linked to the possible $\mathrm{C}$ sequestration induced by $\mathrm{N}$ deposition in ecosystems. Meanwhile, these studies are mostly focused in temperate regions, especially in North American and Europe, where ecosystems commonly belong to glaciated landscapes and are N-limited under natural conditions (e.g. Vitousek and Howarth, 1991; Aber et al., 1998, 2003; Magill et al., 2004). These studies often find that DOC concentration in soil solution increases with elevated $\mathrm{N}$ deposition (Yano et al., 2000; McDowell et al., 2004; Pregitzer et al., 2004; Adams et al., 2005; Findlay, 2005; Sleutel et al., 2009; Rappe-George et al., 2013).

Tropical forest ecosystems, which store approximately $13 \%$ of global soil C, contribute greatly to the global C cycle; thus, even relatively small fluctuations in $\mathrm{C}$ cycling can have global consequences (Post et al., 1982; Phillips et al., 1998; Findlay, 2005; Townsend et al., 2011). In contrast to their temperate and boreal counterparts, many lowland tropical forests are typically $\mathrm{N}$-rich ecosystems as compared with $\mathrm{P}$ availability, with high soil $\mathrm{N}$ availability, rapid rates of $\mathrm{N}$ cycling, and the lack of N limitation to NPP (Vitousek and Sanford, 1986; Matson et al., 1999; Hedin et al., 2009; Wright et al., 2011; Brookshire et al., 2012). However, our understanding of how $\mathrm{N}$ additions control DOC dynamics in these $\mathrm{N}$-rich ecosystems remains far from complete.

The purpose of this study was to examine the effects of how long-term $(7 \mathrm{yr})$ experimental addition of $\mathrm{N}$ affects DOC dynamics in the N-rich tropical forests. In 2002, we established long-term $\mathrm{N}$ deposition research plots in typical N-rich lowland tropical mature forests of Southern China (Mo et al., 2006, 2008; Fang et al., 2009; Lu et al., 2010), where atmospheric $\mathrm{N}$ deposition rates are commonly $>19 \mathrm{~kg} \mathrm{Nha}^{-1} \mathrm{yr}^{-1}$, and are expected to increase greatly in the future due to the rapid development of agricultural and industrial activities (Zhou and Yan, 2001; Galloway et al., 2004; Lü and Tian, 2007; Liu et al., 2011). Because soil solution chemistry can be considered as a sensitive indicator of biogeochemical processes within forest stands, responding quickly to disturbances or stresses such as excess N (e.g. McDowell et al., 2004; Pregitzer et al., 2004; Michel et al., 2006; Gilliam and Adams, 2011), we mainly focused our study on the response of soil solution chemistry to $\mathrm{N}$ addition. Earlier measurements in these forests have indicated no changes in DOC dynamics in response to short-term ( 1 to $2 \mathrm{yr}) \mathrm{N}$ deposition treatment (Fang et al., 2009). In the present study, we expected to find that long-term continuous $\mathrm{N}$ addition to $\mathrm{N}$-rich tropical forests has minimal effect on DOC concen- trations and effluxes, because highly weathered tropical soils commonly have high levels of $\mathrm{N}$ availability and rapid $\mathrm{N}$ cycling (Martinelli et al., 1999; Vitousek and Sanford, 1986; Fang et al., 2009). At the same time, we assumed that mechanisms for $\mathrm{N}$-addition induced changes of DOC dynamics may be different from those of $\mathrm{N}$-limited temperate forests, because of the different $\mathrm{N}$ status.

\section{Materials and methods}

\subsection{Study site}

We carried out our work in the Dinghushan Biosphere Reserve (DBR). This site is part of the UNESCO/MAB network and is within the Guangdong Province of southern China $\left(112^{\circ} 10^{\prime} \mathrm{E}, 23^{\circ} 10^{\prime} \mathrm{N}\right)$. The DBR extends approximately 1200 ha within the subtropical/tropical moist forest life zone. It was established in 1950 for the protection of remnant of undisturbed monsoon evergreen broadleaf forests in the lower subtropics, being the first National Natural Reserve in China in 1956. The monsoon climate of this site averages $1927 \mathrm{~mm}$ precipitation per year with approximately $75 \%$ occurring between March and August, and 6\% between December and February (Huang and Fan, 1982). Relative humidity averages $80 \%$ throughout the year. Mean annual temperature is $21.0^{\circ} \mathrm{C}$, ranging from mean coldest in January $\left(12.6^{\circ} \mathrm{C}\right)$ and hottest in July $\left(28.0^{\circ} \mathrm{C}\right)$. Currently, the region surrounding DBR experiences high rates of atmospheric $\mathrm{N}$ deposition (21-38 $\mathrm{kg} \mathrm{Nha}^{-1} \mathrm{yr}^{-1}$ as inorganic $\mathrm{N}$ in bulk precipitation) (Huang et al., 1994; Zhou and Yan, 2001; Fang et al., 2008). In 2004-2005 wet $\mathrm{N}$ deposition averaged $\sim 33 \mathrm{~kg} \mathrm{~N} \mathrm{ha}^{-1} \mathrm{yr}^{-1}$ (Fang et al., 2008).

We established the research site at DBR in 2002 between 250 and $300 \mathrm{~m}$ above sea level. According to ${ }^{14} \mathrm{C}$ measurement of forest soils, forest stands have been protected from direct human disturbance for $>400 \mathrm{yr}$ (Shen et al., 1999). These support a rich assemblage of plant species, most of which are evergreen tree species native to the tropics and subtropics. These include Castanopsis chinensis Hance, Schima superba Chardn. \& Champ., Cryptocarya chinensis (Hance) Hemsl., Cryptocarya concinna Hance, Machilus chinensis (Champ. Ex Benth.) Hemsl., and Syzygium rehderianum Merr. \& Perry (Cao et al., 2002). Canopy closure is typically above $95 \%$ (Lu et al., 2010). Soils are oxisols (lateritic red earths) formed from sandstone approximately $30 \mathrm{~cm}$ to $70 \mathrm{~cm}$ in depth.

\subsection{Experimental treatments}

The experiments involving $\mathrm{N}$ amendments were established in July 2003 (Mo et al., 2006), with four $\mathrm{N}$ addition rates used: Control (0 $\mathrm{N}$ added $)$, Low- $\mathrm{N}$ $\left(50 \mathrm{~kg} \mathrm{Nha}^{-1} \mathrm{yr}^{-1}\right)$, Medium-N (100 $\left.\mathrm{kg} \mathrm{Nha}^{-1} \mathrm{yr}^{-1}\right)$ and High-N $\left(150 \mathrm{~kg} \mathrm{Nha}^{-1} \mathrm{yr}^{-1}\right)$, which were based on the present atmospheric $\mathrm{N}$ deposition rate and the expected 
increase in the future due to the rapid development of agricultural and industrial activities (Galloway et al., 2004; Lü and Tian, 2007). Considering that any effects of chronic low level $\mathrm{N}$ addition are likely to be similar in direction, if not magnitude, to the short-term effects of high rates of $\mathrm{N}$ addition (e.g. Báez et al. 2007; Clark and Tilman 2008; Lu et al., 2010), results from our present concentration gradients could be as a prediction for the future changes. A $10 \mathrm{~m}$ wide buffer strip surrounded each of $12 \times 10 \mathrm{~m} \times 20 \mathrm{~m}$ plots, with plots and treatments replicated in triplicate and randomly located. A hand-applied $\mathrm{NH}_{4} \mathrm{NO}_{3}$ solution was added each month to the forest floor of each plot as 12 equal, monthly applications per year. Fertilizer was weighed and mixed with $20 \mathrm{~L}$ of deionized water (equivalent of $0.1 \mathrm{~mm}$ rainfall), with solution added via backpack sprayer below the canopy. Two passes were made across each plot to ensure an even distribution of fertilizer. Control plots received an equivalent volume of deionized $\mathrm{H}_{2} \mathrm{O}$.

\subsection{Field water sampling and laboratory analysis}

Precipitation and air temperature were monitored in an open area adjacent to the study plots. The data used in this study were from the weather station in the reserve (Appendix 1).

Soil solution was collected at a $20 \mathrm{~cm}$ depth, a depth which represents the primary rooting zone, and containing $>70 \%$ of fine root biomass and $68 \%$ of total root biomass (Liao et al., 1993; Wen et al., 1999). Soil solution was sampled with two replicate zero tension tray lysimeters $\left(755 \mathrm{~cm}^{2}\right.$ per tray) per plot, which were installed in April/May 2003 (i.e. 34 months prior to our experiment). Each lysimeter was connected with Tygon tubing to a $10 \mathrm{~L}$ bottle.

Soil solution samples were taken after each rain event (particularly after heavy rainstorms) from July 2009 to June 2010. Soil solution volume was recorded and composited within a plot on data of collection. All collectors were washed with deionized $\mathrm{H}_{2} \mathrm{O}$ immediately following each collection.

Within 24 to $48 \mathrm{~h}$ of field collection, soil solution samples were filtered through $0.45 \mathrm{~mm}$ micron filters in the laboratory, then stored in plastic bottles at $4^{\circ} \mathrm{C}$ until chemical analysis, which included $\mathrm{NH}_{4}^{+}-\mathrm{N}, \mathrm{NO}_{3}^{-}-\mathrm{N}, \mathrm{DOC}$, and pH. A Shimadzu TOC-VCSH Total Organic Carbon analyzer was used to determine DOC, with samples combusted at $680^{\circ} \mathrm{C}$ via platinum catalyst and $\mathrm{CO}_{2}$ determined with a non-dispersive infrared (NDIR) detector. Samples were analyzed for dissolved inorganic nitrogen $\left(\mathrm{NH}_{4}^{+}-\mathrm{N}\right.$ and $\left.\mathrm{NO}_{3}^{-}-\mathrm{N}\right)$ using a Lachat QC8000 Flow Injection Analyzer.

\subsection{Field soil sampling and laboratory analysis}

Samples of mineral soil were collected in August 2009 with a $5 \mathrm{~cm}$ diameter corer at $0-10$ and $10-20 \mathrm{~cm}$ depths. From $0-10 \mathrm{~cm}$, cores were taken beneath the loose litter layer (Oi) and comprised a fermented (Oe) and a humified (Oa) organic layer, plus mineral soil to a total depth of $10 \mathrm{~cm}$. Following this, the corer was driven to a $20 \mathrm{~cm}$ depth for sample collection. Sampling in each plot took place in three randomlyselected locations.

In the laboratory, roots and stones were removed by sieving soil to pass a 2-mm screen; sieved soils mixed thoroughly by hand. For water-extractable DOC (WDOC) measurements, one $10 \mathrm{~g}$ sub-sample from each sample was extracted with $50 \mathrm{ml}$ of deionized $\mathrm{H}_{2} \mathrm{O}$ for $30 \mathrm{~min}$ and filtered through $0.45 \mu \mathrm{m}$ cellulose-acetate filters, as modified from Hagedorn et al. (2002). Water-extractable DOC was determined with a Shimadzu TOC analyzer as previously described. Other subsamples were air-dried and used to measure $\mathrm{pH}$ (soil : water $=1: 2.5$ ) and nutrient content. Total C (total soil organic C) was measured via titration with $\mathrm{Fe}^{2+}$ solution following dichromate oxidation (Liu et al., 1996). Total $\mathrm{N}$ was determined by determination of $\mathrm{NH}_{4}^{+}$following semi-micro Kjeldahl digestion (Liu et al., 1996). Exchangeable $\mathrm{Fe}$ and $\mathrm{Al}$ were extracted with $0.1 \mathrm{~mol} \mathrm{~L}^{-1} \mathrm{BaCl}_{2}(50: 1$, solution : soil). Subsamples of soil were oven-dried at $105^{\circ} \mathrm{C}$ to a constant weight (at least $24 \mathrm{~h}$ ) to allow reporting soil results on an oven-dry basis.

\subsection{Field litterfall sampling}

Two $1 \mathrm{~m} \times 1 \mathrm{~m}$ litter traps with a $1 \mathrm{~mm}$ mesh size were placed randomly in each plot at an approximate $0.5 \mathrm{~m}$ height above ground surface. Traps were emptied each month during the year, with litterfall separated into three components: leaves, small woody material (branches and bark), and miscellaneous (mainly reproductive parts).

\subsection{Data analyses}

Monthly and annual $\mathrm{C}$ effluxes from the primary rooting zone for each plot were calculated by multiplying DOC concentrations of soil leachate by the recorded water volume for each sample collection and then summed appropriately. We calculated mean values per month for $\mathrm{NH}_{4}^{+}-\mathrm{N}, \mathrm{NO}_{3}^{-}-\mathrm{N}, \mathrm{DOC}$ and $\mathrm{pH}$ in water samples for further analysis. Effects of $\mathrm{N}$ treatments on soil solution chemistry $\left(\mathrm{NH}_{4}^{+}-\mathrm{N}, \mathrm{NO}_{3}^{-}-\mathrm{N}\right.$, DOC and $\mathrm{pH}$ ) and litterfall during the study period were assessed with repeated measure analysis of variance (ANOVA). Oneway ANOVA with Tukey's honestly significantly different (Tukey's HSD) test was used to test $\mathrm{N}$ treatment effects on concentrations of $\mathrm{NH}_{4}^{+}-\mathrm{N}$ and $\mathrm{NO}_{3}^{-}-\mathrm{N}, \mathrm{pH}$, and annual DOC effluxes for the whole study period. One-way ANOVA with Tukey's HSD test was also employed to identify $\mathrm{N}$ treatment effects on soil properties (soil $\mathrm{pH}$, concentrations of total $\mathrm{C}$ and $\mathrm{N}, \mathrm{C} / \mathrm{N}$ ratios, and extractable $\mathrm{Fe}$ and $\mathrm{Al}$ ) and WDOC. Extractable $\mathrm{Fe}$ and $\mathrm{Al}$ pools were estimated by multiplying extractable concentrations by soil bulk density, which were taken from the Dinghushan research station. We conducted the planned contrast analysis to test for differences between Control plots and $\mathrm{N}$-treatment plots. 
We also used general linear models to analyze relationships between DOC concentrations and $\mathrm{pH}$ for soil solution sampled at $20 \mathrm{~cm}$ depth in all plots during the study period. Linear regression analysis was also used to examine the relationship between mean DOC of $\mathrm{cm}$ soil solution at $20 \mathrm{~cm}$ depth and extractable $\mathrm{Fe}$ and $\mathrm{Al}$ pools in the upper $20 \mathrm{~cm}$ soil, respectively. All analyses were conducted using SPSS 14.0 for Windows ${ }^{\circledR}$ (SPSS, Chicago, IL, USA), with significant differences set with $P<0.05$, unless otherwise stated.

\section{Results}

During the study period (July 2009-June 2010), the total precipitation was $1992 \mathrm{~mm}$, most falling during the March to August wet season (Appendix 1). Mean monthly precipitation in the wet season $(245 \mathrm{~mm})$ nearly three times that of the dry season $(88 \mathrm{~mm})$. Mean monthly temperature was $22.2^{\circ} \mathrm{C}$. Total wet $\mathrm{N}$ deposition was $34.4 \mathrm{~kg} \mathrm{Nha}^{-1}$, with $18.2 \mathrm{~kg} \mathrm{ha}^{-1}$ dissolved inorganic $\mathrm{N}\left(7.7 \mathrm{~kg} \mathrm{ha}^{-1} \mathrm{NO}_{3}^{-}\right.$$\mathrm{N}$ and $10.5 \mathrm{~kg} \mathrm{ha}^{-1} \mathrm{NH}_{4}^{+}-\mathrm{N}$, respectively) and $16.2 \mathrm{~kg} \mathrm{ha}^{-1}$ dissolved organic $\mathrm{N}$, respectively.

\subsection{DOC concentration and effluxes}

The repeated measures ANOVA revealed that $\mathrm{N}$ additions significantly decreased the DOC concentrations and DOC effluxes at $20 \mathrm{~cm}$ depth over the study period $(\mathrm{df}=3, F=$ $21.4, P=0.001 ; \mathrm{df}=3, F=6.8, P=0.02$, respectively) (Fig. 1a and c). There were also significant interaction effects between treatment and time (months) on DOC concentrations and effluxes $(\mathrm{df}=33, F=3.6, P<0.001$; $\mathrm{df}=33$, $F=2.1, P=0.006$, respectively). For DOC concentrations, the decreased trends were more pronounced in Medium-N and High-N plots than that of Low-N plots, and relative measures showed they decreased by $15 \%, 28 \%$ and $31 \%$ in the Low-N, Medium-N and High-N plots, respectively, relative to that of the Control plots over the whole year (Fig. 1b). For DOC effluxes, they decreased by $44 \%, 34 \%$ and $18 \%$ in the Low-N, Medium-N, and High-N plots, respectively (Fig. 1d).

Mean DOC concentrations in the Medium-N and High$\mathrm{N}$ treatments were significantly lower than that of the Controls $(P<0.05$; Table 1$)$. Further analysis showed that $\mathrm{N}$ additions decreased annual DOC effluxes at $20 \mathrm{~cm}$, especially in the Low- $\mathrm{N}$ and Medium-N plots, where the decreases were significant $(P<0.05$; Table 1$)$. Planned contrast analysis showed that there were significant $\mathrm{N}$-treatment effects for both mean DOC concentrations and annual DOC effluxes. The annual DOC effluxes were 99.6, 63.6, 61.0, and $79.1 \mathrm{~kg} \mathrm{Cha}^{-1} \mathrm{yr}^{-1}$ in the Control, Low-N, Medium-N and High-N plots, respectively.
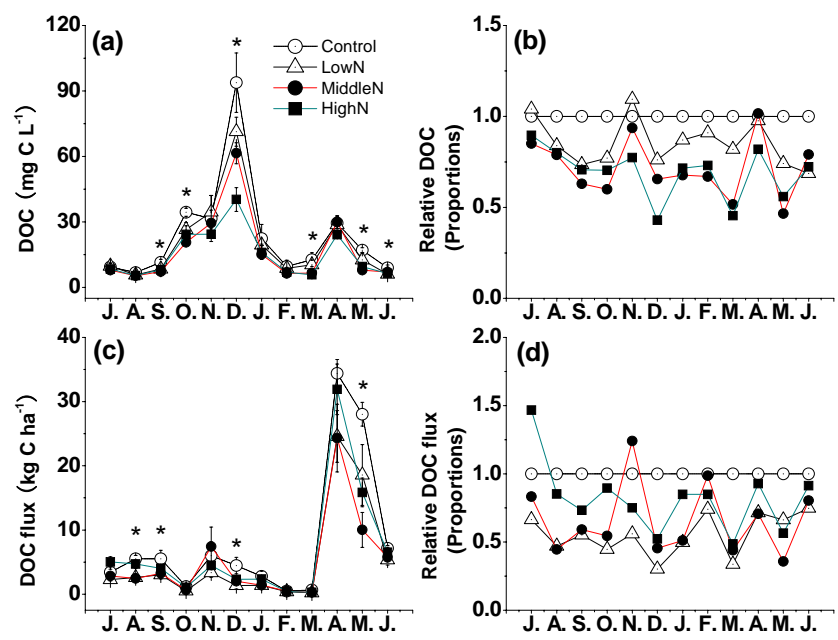

(d)

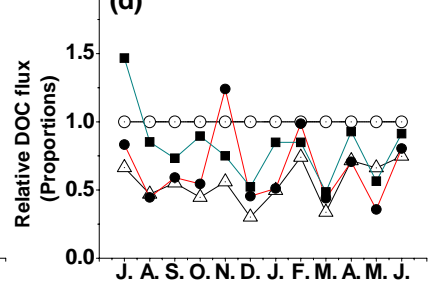

Fig. 1. Responses of DOC concentration (a) and its relative concentration (b), and DOC efflux (c) and its relative efflux (d) to long-term $\mathrm{N}$ addition below the primary rooting zone in the lowland tropical forests of Southern China. Soil leachate data were available from July 2009 to June 2010. Notes: Asterisk (*) indicates that there are significant differences at $P<0.05$ level between $\mathrm{N}$ treatments and the Controls using planned contrast analysis.

\section{2 $\mathrm{NO}_{3}^{-}-\mathrm{N}, \mathrm{NH}_{4}^{+}-\mathrm{N}$ and $\mathrm{pH}$ in soil solution}

The concentrations of $\mathrm{NO}_{3}^{-}-\mathrm{N}$ in $\mathrm{N}$-treatment plots were generally higher than that of the Controls (Fig. 2a), and the mean concentrations of $\mathrm{NO}_{3}^{-}-\mathrm{N}$ across the whole study period increased, but not significant, in the $\mathrm{N}$-treatment plots $(P=0.099$; Table 1), although repeated measures ANOVA revealed that $\mathrm{N}$ additions did not significantly increase concentrations of $\mathrm{NO}_{3}^{-}-\mathrm{N}(\mathrm{df}=3, F=2.4, P=0.16)$.

Concentrations of $\mathrm{NH}_{4}^{+}-\mathrm{N}$ (commonly less than $1 \mathrm{mg} \mathrm{N}$ $\mathrm{L}^{-1}$ as mean values for the whole period) were much lower than those of $\mathrm{NO}_{3}^{-}-\mathrm{N}$ at all plots (Fig. 2b). There were no significant responses to $\mathrm{N}$ treatments across all plots and sampling times. This is further confirmed by the result of repeated measures ANOVA ( $\mathrm{df}=3, F=1.4, P=0.34$ ). In addition, the mean concentrations of $\mathrm{NH}_{4}^{+}-\mathrm{N}$ across the whole study period also showed no significant differences between $\mathrm{N}$ treatments and Controls (Table 1).

Repeated measures ANOVA showed that $\mathrm{N}$ additions significantly decreased soil solution $\mathrm{pH}$ it at $20 \mathrm{~cm}$ depth $(\mathrm{df}=$ $3, F=42, P<0.001)$. Similarly, across the whole study period, $\mathrm{N}$ treatments changed significantly $(P=0.001)$ the mean values of soil solution $\mathrm{pH}$, especially in the High-N plots (Table 1). 
Table 1. Effects of $\mathrm{N}$ addition on average concentrations of DOC, $\mathrm{NO}_{3}^{-}-\mathrm{N}, \mathrm{NH}_{4}^{+}-\mathrm{N}$, and $\mathrm{pH}$, and annual DOC efflux in soil solutions below the primary rooting zones (0-20 cm soils) during the periods from July 2009 to June 2010 . The different lowercase letters indicate significant differences at $P<0.05$ level, and no letters indicate no significant differences among $\mathrm{N}$ treatment levels, respectively (Tukey's HSD test); Contrast Test is conducted between $\mathrm{N}$ treatments and the Controls using planned contrast analysis. Values are mean with SE in parentheses.

\begin{tabular}{|c|c|c|c|c|c|}
\hline $\mathrm{N}$ treatments & $\begin{array}{l}\mathrm{DOC} \\
\left(\mathrm{mg} \mathrm{L}^{-1}\right)\end{array}$ & $\begin{array}{l}\text { DOC efflux } \\
\mathrm{kgCha}^{-1} \mathrm{yr}^{-1}\end{array}$ & $\begin{array}{l}\mathrm{NO}_{3}^{-}-\mathrm{N} \\
\left(\mathrm{mg} \mathrm{L}^{-1}\right)\end{array}$ & $\begin{array}{l}\mathrm{NH}_{4}^{+}-\mathrm{N} \\
\left(\mathrm{mg} \mathrm{L}^{-1}\right)\end{array}$ & $\mathrm{pH}$ \\
\hline Control & $23.96(2.18) \mathrm{a}$ & $99.61(2.63) \mathrm{a}$ & $9.74(0.92)$ & $0.24(0.01)$ & $3.81(0.01) \mathrm{a}$ \\
\hline Low-N & $20.19(1.16) \mathrm{ab}$ & $63.62(6.25) b$ & $11.26(0.40)$ & $0.23(0.01)$ & $3.78(0.01) \mathrm{a}$ \\
\hline Medium-N & $17.10(0.92) \mathrm{b}$ & $60.99(8.87) \mathrm{b}$ & $11.74(0.82)$ & $0.24(0.03)$ & $3.78(0.00) \mathrm{a}$ \\
\hline High-N & $14.98(0.46) b$ & $79.06(3.73) \mathrm{ab}$ & $14.04(2.05)$ & $0.45(0.20)$ & $3.70(0.01) \mathrm{b}$ \\
\hline Contrast Test & $P=0.003$ & $P=0.002$ & $P=0.099$ & $P=0.58$ & $P=0.001$ \\
\hline
\end{tabular}
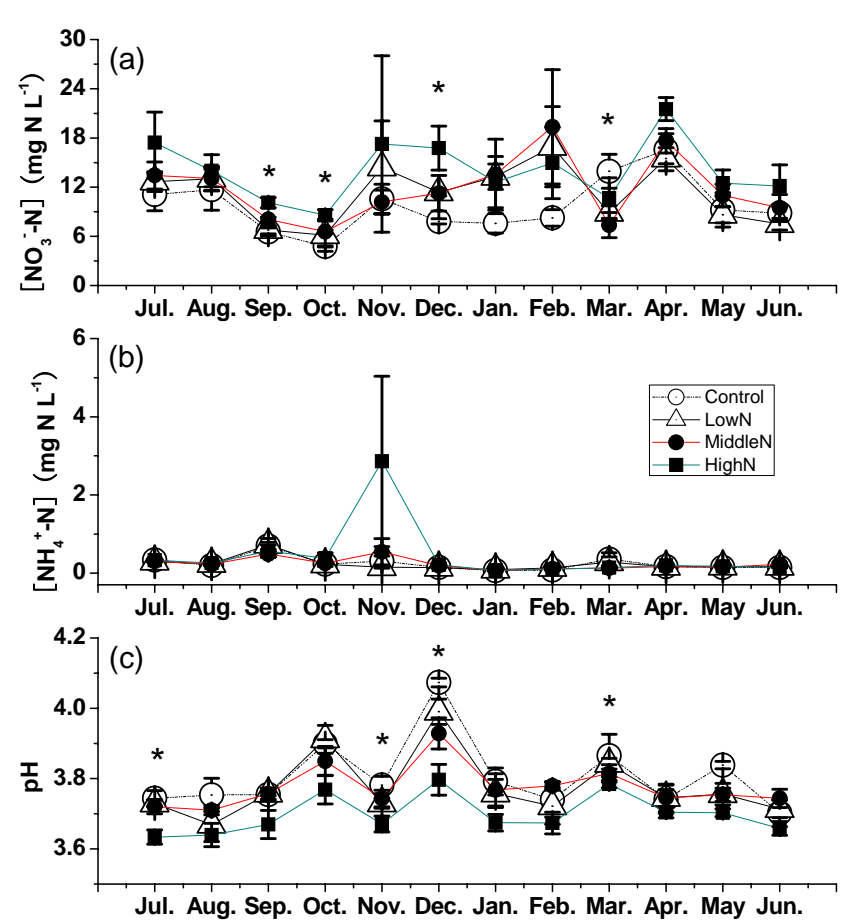

Fig. 2. Responses of $\mathrm{NO}_{3}^{-}-\mathrm{N}\left(\right.$ a), $\mathrm{NH}_{4}^{+}-\mathrm{N}(\mathbf{b})$ and $\mathrm{pH}$ (c) dynamics to long-term $\mathrm{N}$ addition in soil solution below the dominant rooting zone in the lowland tropical forests of Southern China. Asterisk (*) indicates that there are significant differences at $P<0.05$ level between $\mathrm{N}$ treatments and the Controls using planned contrast analysis.

\subsection{Soil chemistry and litterfall}

Total soil $\mathrm{N}$ and $\mathrm{C}$ and extractable $\mathrm{Al}$ and $\mathrm{Fe}$ showed increasing trends with elevated $\mathrm{N}$ addition (Table 2). Total $\mathrm{N}$ increased by $8 \%, 12 \%, 17 \%$ in the Low-N, Medium$\mathrm{N}$, and High- $\mathrm{N}$ treatment plots, respectively, compared to the Controls; total $\mathrm{C}$ increased by $10 \%, 13 \%, 17 \%$ in the Low-N, Medium-N, and High-N treatment plots, respectively, compared to Controls. High-N treatments also showed marginally significant effects on total $\mathrm{C}(P=0.08)$, and sig-

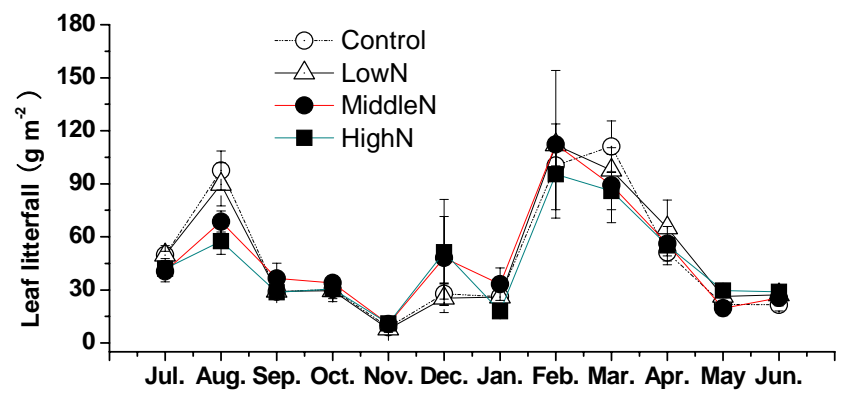

Fig. 3. Monthly dynamics of litterfall with elevated $\mathrm{N}$ addition in the lowland tropical forests of Southern China during the study period.

nificant effects on extractable $\mathrm{Fe}(P=0.03)$. Soil $\mathrm{pH}$ values decreased with increasing $\mathrm{N}$ treatment levels, especially in the Medium-N and High-N plots $(P>0.1)$. Further analysis showed that there were significantly linear relationships between treatment levels and $\mathrm{pH}$ across all plots $\left(R^{2}=0.54\right.$, $N=12, P=0.006$ ). There was no significant difference among treatments for soil $\mathrm{C} / \mathrm{N}$ ratios. For WDOC, $\mathrm{N}$ additions increased their contents in this upper $0-20 \mathrm{~cm}$ soil, where the increases were significant under $\mathrm{N}$ treatments compared to the Controls ( $P=0.032$; Table 2). Annual litterfall was not significantly different among treatments (Fig. 3).

\subsection{Relationships between DOC, extractable Fe and Al, and pH}

Linear model analysis showed that DOC concentrations were significantly and positively correlated with $\mathrm{pH}\left(R^{2}=\right.$ $0.4 ; N=144 ; P<0.001)$ in soil solution across all sampling data (Fig. 4). Meanwhile, extractable Al pool was not significantly correlated with mean DOC concentration in the soil solution at $20 \mathrm{~cm}$ soils $\left(R^{2}=0.004, N=12, P=0.84\right.$; Fig. 5a), but extractable Fe pool exhibited significant and negative correlations with DOC $\left(R^{2}=0.42, N=12, P=\right.$ 0.023) (Fig. 5b). 
Table 2. Responses of soil chemistry in the primary rooting zones $(0-20 \mathrm{~cm}$ soils $)$ to $\mathrm{N}$ addition in the lowland tropical forest of Southern China in August, 2009. The different lowercase letters indicate significant differences at $P<0.05$ level, and no letters indicate no significant differences among N treatment levels, respectively (Tukey's HSD test). Contrast Test is conducted between N treatments and the Controls using planned contrast analysis.

\begin{tabular}{llllll}
\hline \multirow{2}{*}{ Parameters } & \multicolumn{5}{c}{$\mathrm{N}$ treatments } \\
\cline { 2 - 5 } & Control & Low-N & Medium-N & High-N & Contrast Test \\
\hline Total N (mg g & & & & \\
Total C $\left(\mathrm{mg} \mathrm{g}^{-1}\right)$ & $1.90(0.11)$ & $2.05(0.08)$ & $2.13(0.09)$ & $2.22(0.06)$ & $P=0.045$ \\
$\mathrm{C} / \mathrm{N} \mathrm{ratio}$ & $11.88(0.40)$ & $24.17(0.97)$ & $24.82(0.50)$ & $25.64(1.44)$ & $P=0.023$ \\
WDOC $\left(\mathrm{mg} \mathrm{Kg}^{-1}\right)$ & $107.43(8.24)$ & $160.92(25.55)$ & $140.10(10.97)$ & $179.20(20.30)$ & $P=0.032$ \\
$\mathrm{Al}^{3+}\left(\mathrm{m} \mathrm{mol} \mathrm{kg}^{-1}\right)$ & $30.50(1.31)$ & $30.54(2.78)$ & $31.49(1.66)$ & $31.54(1.60)$ & $P=0.67$ \\
$\mathrm{Fe}^{3+}\left(\mathrm{m} \mathrm{mol} \mathrm{kg}^{-1}\right)$ & $0.12(0.013) \mathrm{a}$ & $0.17(0.018) \mathrm{ab}$ & $0.17(0.020) \mathrm{ab}$ & $0.20(0.010) \mathrm{b}$ & $P=0.012$ \\
$\mathrm{pH}\left(\mathrm{H}_{2} \mathrm{O}\right)$ & $3.87(0.02)$ & $3.84(0.00)$ & $3.75(0.05)$ & $3.75(0.04)$ & $P=0.045$ \\
\hline
\end{tabular}

Notes: Total C means total soil organic carbon; WDOC means water-extracted dissolved organic carbon; Values are means with SE in parentheses.

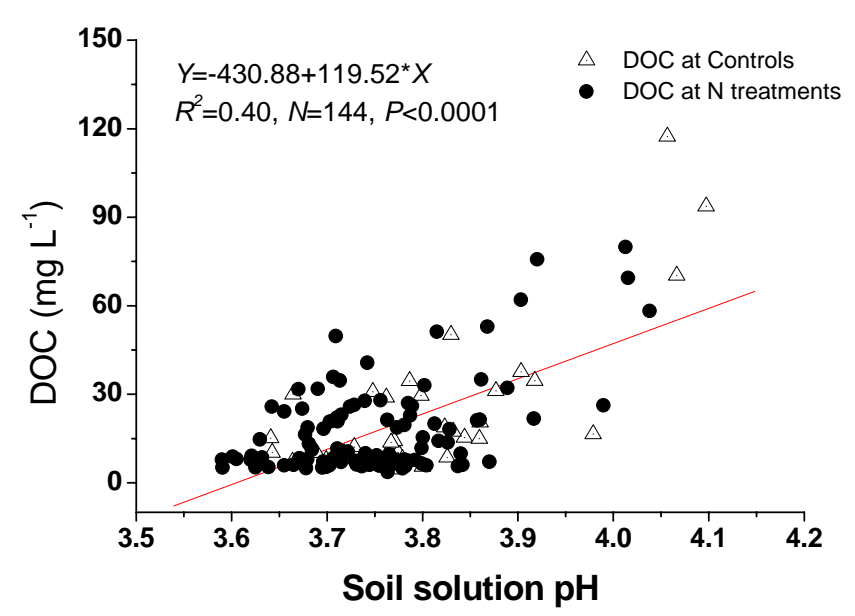

Fig. 4. Relationships between DOC concentrations and $\mathrm{pH}$ in soil solutions across all plots during the study period. Notes: Triangles $(\Delta)$ indicate DOC concentration at control plots, and solid circles $(\bullet)$ indicate DOC concentration at $\mathrm{N}$-treatments plots.

\section{Discussions}

\subsection{Effects of $\mathrm{N}$ addition on DOC leaching}

Earlier measurements in the year 2005 at our site showed that $\mathrm{N}$ addition had no significant effects on soil solution DOC concentrations below the primary rooting zone (Fang et al., 2009). Current results, however, indicate that $\mathrm{N}$ treatments significantly decreased DOC concentrations in soil solution from this layer, suggesting that responses of DOC dynamics to $\mathrm{N}$ addition may be time-dependent in $\mathrm{N}$-rich tropical forests. This rejects our initial hypothesis, and also contrasts with other studies in primarily N-limited ecosystems. In Nlimited forests, increased $\mathrm{N}$ availability generally results in more DOC production and subsequent leaching (Pregitzer et al., 2004; Findlay, 2005; Adams et al., 2005; Sleutel et al.,
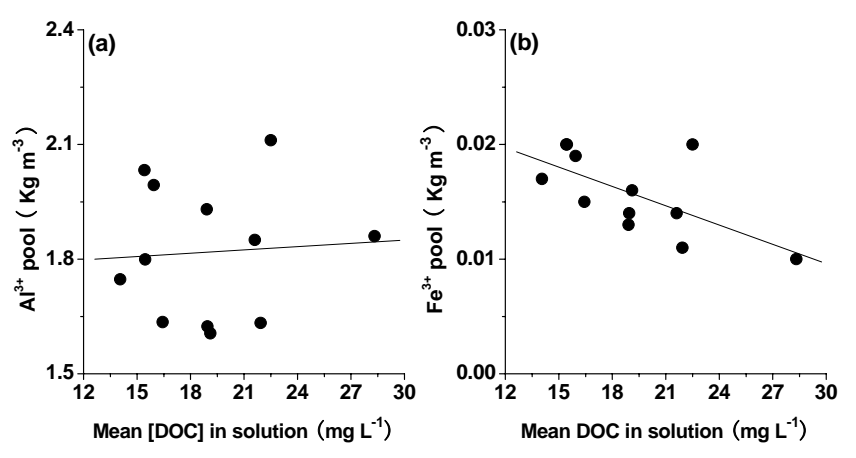

Fig. 5. Relationships between mean DOC concentrations in soil solution and soil extractable $\mathrm{Al}\left(\mathbf{a} ; Y=1.76+0.003 \cdot X, R^{2}=0.004\right.$, $P=0.84)$ and $\mathrm{Fe}\left(\mathbf{b} ; Y=0.026-5.62 \times 10^{-4} \cdot X, R^{2}=0.42, P=\right.$ 0.023 ) pools in upper $0-20 \mathrm{~cm}$ mineral soils.

2009). Smemo et al. (2007) reported that deposition added as $\mathrm{NaNO}_{3}$ significantly increased soil solution DOC concentration and export from four different northern hardwood forests in the Great Lakes region. McDowell et al. (1998, 2004) found greater concentrations of DOC following the addition of $50-150 \mathrm{~kg} \mathrm{Nha}^{-1} \mathrm{yr}^{-1}$ as $\mathrm{NH}_{4} \mathrm{NO}_{3}$. Sleutel et al. (2009) provide additional evidence on higher concentrations of DOC in boreal forests of Belgium under historic high $\mathrm{N}$ deposition.

Biological mechanisms (balance between processes that produce and consume DOC) are often suggested to explain changes of DOC concentrations in leachate with elevated $\mathrm{N}$ addition in typically N-limited ecosystems (Neff and Asner, 2001; Knorr et al., 2005; Zak et al., 2008; Evans et al., 2008). Pregitzer et al. (2004) suggested that increases in DOC were primarily biologically driven, resulting from changes in production of organic substrates and processing within soil food webs. Bragazza et al. (2006) indicated that the increased release of DOC from litter peat was a consequence of enhanced 
enzymatic activity (e.g. phenol oxidase). In these studies, litterfall is the major source of DOC to the forest floor and thus deeper soil horizons with elevated $\mathrm{N}$ deposition (Currie et al., 1996; Magill and Aber, 2000; Park et al., 2002; Sleutel et al., 2009). Gundersen et al. (1998) showed a significant correlation between DOC concentration beneath the forest floor $(\mathrm{Oa}$ horizon) and litterfall amount. In a meta-analysis from multiple terrestrial ecosystems, Liu and Greaver (2010) found that $\mathrm{N}$ addition increased soil DOC concentration by an average of $18 \%$, although soil respiration was not altered, suggesting $\mathrm{C}$ leaching loss may increase in $\mathrm{N}$-limited ecosystems.

In our $\mathrm{N}$-rich forest, however, there were no significant effects of $\mathrm{N}$ treatments on litterfall production (Mo et al., 2008; Fig. 3); at the same time, there was no significant difference between $\mathrm{N}$ treatments in DOC dynamics in surface runoff (data not shown), suggesting that litterfall inputs may play a minor role in DOC production and subsequent fluxes into deeper soils under $\mathrm{N}$ treatments. Further studies showed that $\mathrm{N}$ addition significantly inhibited litter decomposition and decreased soil respiration in this forest (Mo et al., 2006, 2008). In addition, $C$ mineralization, which is the conversion from the organic $\mathrm{C}$ form to inorganic compound as a result of decomposition reactions (Carter and Gregorich, 2008), is suggested to result in high absolute loss of DOC (Chantigny et al., 1999; Huang and Schoenau, 1998; Sjöberg et al., 2003). An incubation experiment on these forest soils, however, showed that $\mathrm{N}$ addition decreased organic $\mathrm{C}$ mineralization (Ouyang et al., 2008), indicating that elevated $\mathrm{N}$ inputs may contribute to soil DOC accretion in the deeper soil by decreasing DOC decomposition/consumption. Our findings support this suggestion in that $\mathrm{N}$ addition greatly increased water-extractable DOC (Table 2), a finding also supported by other studies (e.g. Hagedorn et al., 2002; Sinsabaugh et al., 2004; Gallo et al., 2005). Increases in extractable DOC under experimental $\mathrm{N}$ additions are generally suggested to increase regional and global DOC effluxes from terrestrial ecosystems to aquatic ecosystems (Pregitzer et al., 2004; Findlay, 2005; Mo et al., 2008; Chapin et al., 2009). However, our results showed that $\mathrm{N}$ treatments decreased DOC concentrations in leachate solutions. Therefore, biological control mechanisms are unlikely responsible for declines in DOC in soil leachate of this $\mathrm{N}$-rich tropical forest.

Indeed, as suggested by Neff and Asner (2001), physical controls may also play an important role in dominating DOC transformations in soils. Here, we propose that both changes in solution acidity and soil sorption dynamics play a dominant role in regulating DOC losses from N-rich ecosystems.

For example, acidity of soil solution may regulate the patterns of DOC responses. It has been recognized that the increase of soil solution $\mathrm{pH}$ (or acid neutralizing capacity) would lead to the net positive changes in DOC concentration by increasing DOC solubility in soil (Monteith et al., 2007; Evans et al., 2008). This was demonstrated by Evans et al. (2008) while reviewing field $\mathrm{N}$ addition experiments in Europe and North American. It has been widely accepted that high $\mathrm{N}$ deposition could accelerate soil acidification and have the potential to change the acidity of soil solution (Aber et al., 1998; Vitousek et al., 1997; Bowman et al., 2008; Van den Berg et al., 2008). In this study, we found that $\mathrm{N}$ treatments significantly decreased soil solution $\mathrm{pH}$ below the dominant rooting zone. Further analysis showed that there was a significant and positive relationship between soil solution $\mathrm{pH}$ and DOC concentration.

It should be noted that the effect of $\mathrm{pH}$ on DOC dynamics may be confounded with other mechanism related to soil properties, for example, sesquioxides in the mineral soil (Moore et al., 1992; Guggenberger, 1994; Michalzik et al., 2001). Thus, we suggest an alternative mechanism for our observations. Soils containing high concentrations of extractable $\mathrm{Fe}$ or/and $\mathrm{Al}$ exhibit the capacity to adsorb DOC as water percolates down through the soil profiles, thereby decreasing DOC concentrations (Boudot et al., 1989; Guggenberger, 1994; Kaiser and Guggenberger, 2000; Sleutel et al., 2009). Corre et al. (2010) suggested that sorption by hydrous $\mathrm{Al}$ oxides could be an important reason for $\mathrm{N}$-induced decreases of soil solution DOC. In our study, however, the extractable Al did not vary significantly among Controls and $\mathrm{N}$-treatment plots, and there were no significant relationships between the extractable $\mathrm{Al}$ pool and mean DOC concentration (Table 2, Fig. 4a). By contrast, $\mathrm{N}$ addition significantly increased extractable Fe. Also, there was a significant negative relationship between extractable Fe pool and mean DOC concentration at $20 \mathrm{~cm}$ soil solution (Fig. 4b). Accordingly, it is possible that extractable $\mathrm{Fe}$, rather than extractable $\mathrm{Al}$, may play a key role in DOC adsorption in $\mathrm{N}$-treatment plots after long-term $\mathrm{N}$ inputs. A better understand how $\mathrm{Fe}$ and $\mathrm{Al}$ oxides control DOC dynamics in tropical forests merits further study.

\subsection{Effects of $\mathbf{N}$ addition on annual DOC effluxes}

Annual DOC effluxes below the $20 \mathrm{~cm}$ rooting zones in our study ranged from $60-100 \mathrm{~kg} \mathrm{Cha}^{-1} \mathrm{yr}^{-1}$, well within the range $\left(30-139 \mathrm{~kg} \mathrm{Cha}^{-1} \mathrm{yr}^{-1}\right)$ reported for tropical forests by Aitkenhead and McDowell (2000). Our results demonstrated that long-term $\mathrm{N}$ addition decreased annual DOC effluxes from the primary rooting zones, especially in the Low$\mathrm{N}$ and Medium-N plots. Considering that there were no significant differences for annual water effluxes among treatments (data now shown), DOC concentration may dominate DOC effluxes, and lower DOC concentration led to the decreased DOC fluxes under N-treatments. The decreases in annual DOC effluxes indicated that soils may accumulate much more DOC with elevated $\mathrm{N}$ addition, consistent with the significant increase of water-extractable DOC at $0-20 \mathrm{~cm}$ soil layer in $\mathrm{N}$-treatment plots (Table 2), and suggesting that elevated $\mathrm{N}$ deposition might enhance soil $\mathrm{C}$ sequestration by decreasing DOC effluxes in N-rich forests.

Zhou et al. (2006) found that this old-growth forest could accumulate soil C $(0-20 \mathrm{~cm}$ depth) at about 
$610 \mathrm{~kg} \mathrm{Cha}^{-1} \mathrm{yr}^{-1}$ over the last two decades, but concluded that the reason for this accumulation was unclear. Our results showed that $\mathrm{N}$-induced net $\mathrm{C}$ sequestration (via reduced DOC efflux, calculated by the difference between $\mathrm{N}$-treatment plots and the Controls) was about 36, 39, $21 \mathrm{~kg} \mathrm{Cha}^{-1} \mathrm{yr}^{-1}$ in the Low-N, Medium-N, and High-N plots, respectively, with a mean value of $32 \mathrm{~kg} \mathrm{C}^{-1} \mathrm{yr}^{-1}$ in $\mathrm{N}$ treatment plots, relative to controls (Table 1). In fact, we have found that $\mathrm{N}$ treatments significantly increased soil total $\mathrm{C}$ after long-term $\mathrm{N}$ addition (Table 2). Therefore, such decreases in annual DOC effluxes may explain, in part, this accumulation of soil C observed by Zhou et al. (2006) considering the high $\mathrm{N}$ deposition during the past decades in this region.

\subsection{Implications}

We have studied effects of long-term $\mathrm{N}$ additions on DOC dynamics of soil solution in N-rich lowland tropical forests under a warm and humid climate. Our results showed that long-term $\mathrm{N}$ additions significantly decreased DOC concentrations in soil solution of deeper soils. It was suggested that chemo-physical controls (solution acidity change and soil sorption) rather than biological controls could play a dominant role in regulating DOC losses from N-rich ecosystems, in contrast to that of $\mathrm{N}$-limited ecosystems. We further found that $\mathrm{N}$ addition decreased greatly annual DOC effluxes below the primary rooting zones, and increased water-extractable DOC in soils. It is suggested that DOC constitutes an important carbon efflux to forested mineral soils (Schwesig et al., 2003), and DOC adsorbed by soils may contribute to the stock of organic $\mathrm{C}$ accumulating during soil development (Qualls and Bridgham, 2005). Therefore, our results indicate that long-term $\mathrm{N}$ deposition could increase soil $\mathrm{C}$ sequestration in the upper soils by decreasing DOC efflux in N-rich forests, which may support a novel mechanism responsible for continuing to accumulate $\mathrm{C}$ in old-growth forests (Zhou et al., 2006; Luyssaert et al., 2008). Thus, this study may give us a new understanding on forests ecosystem $\mathrm{C}$ cycling and possible $\mathrm{C}$ sequestration, and also support data bases for model predictions in $\mathrm{N}$-rich ecosystems, with the globalization of $\mathrm{N}$ deposition. Although our findings would be typical for other N-rich sites, however, our results and corresponding control mechanism should be further validated in various tropical ecosystems in the future with elevated $\mathrm{N}$ deposition.

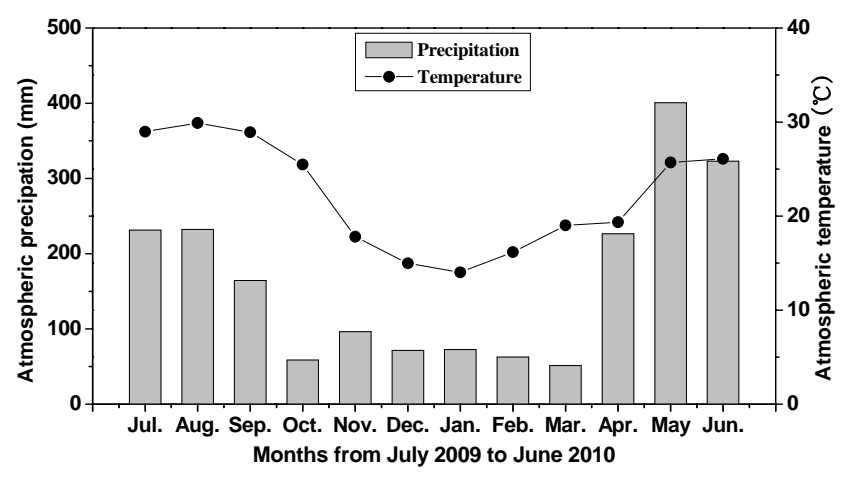

Fig. A1. Monthly precipitation and monthly mean air temperature at Dinghushan Biosphere Reserve, Southern China, during this study period.

Acknowledgements. This study was founded by the National Basic Research Program of China (2010CB833502), National Natural Science Foundation of China (No. 30900202, 30970521), and the Knowledge Innovation Program of the Chinese Academy of Sciences (Grant No. KSCX2-EW-J-28). We wish to thank Dinghushan Forest Ecosystem Research Station for the strong support in the field work, and Guoyi Zhou, Deqiang Zhang, Sandra Brown, Zhi'an Li, Weixing Zhu, Wei Zhang and Juan Huang for invaluable suggestions in this paper, and Shaowei Chen and Hongying Li for their skilful assistance in laboratory work.

Edited by: Z. Jia

\section{References}

Aber, J., McDowell, W., Nadelhoffer, K., Magill, A., Berntson, G., Kamakea, M., McNulty, S., Currie, W., Rustad, L., and Fernandez, I.: 1998: Nitrogen saturation in temperate forest ecosystems, Hypotheses revisited, Bioscience, 48, 921-934, 1998.

Aber, J. D., Goodale, C. L., Ollinger, S. V., Smith, M.-L., Magil, A. H., Martin, M. E., Hallett, R. A., and Stoddard, J. L.: Is nitrogen deposition altering the nitrogen status of Northeastern forests?, Bioscience, 53, 375-389, 2003.

Adams, A. B., Harrison, R. B., Sletten, R. S., Strahm, B. D., Turnblom, E. C., and Jensen, C. M.: Nitrogen-fertilization impacts on carbon sequestration and flux in managed coastal Douglas-fir stands of the Pacific Northwest, Forest Ecol. Manag., 220, 313325, 2005.

Aitkenhead, J. A., and McDowell, W. H.: Soil C:N ratio as a predictor of annual riverine DOC flux at local and global scales, Global Biogeochem. Cy., 14, 127-138, 2000.

Báez, S., Fargione, J., Moore, D. I., Collins, S. L., and Gosz, J. R.: Atmospheric nitrogen deposition in the northern Chihuahuan Desert: temporal trends and potential consequences, J. Arid Environ., 68, 640-651, 2007.

Boudot, J. P., Belhadjbrahim, A., Steiman, R., and Seiglemurandi, F.: Biodegradation of synthetic organo-metallic complexes of iron and aluminium with selected metal to carbon ratios, Soil Biol. Biochem., 21, 961-966, 1989. 
Bowman, W. D., Cleveland, C. C., Halada, L., Hresko, J., and Baron, J. S.: Negative impact of nitrogen deposition on soil buffering capacity, Nat. Geosci., 1, 767-770, 2008.

Brookshire, E. N. J., Gerber, S., Menge, D. N. L., and Hedin, L. O.: Large losses of inorganic nitrogen from tropical rainforests suggest a lack of nitrogen limitation, Ecol. Lett., 15, 9-16, 2012.

Bragazza, L., Freeman, C., Jones, T., Rydin, H., Limpens, J., Fenner, N., Ellis, T., Gerdol, R., Hájek, M., Hájek, T., Iacumin, P., Kutnar, L., Tahvanainen, T., and Toberman, H.: Atmospheric nitrogen deposition promotes carbon loss from peat bogs, P. Natl. Acad. Sci. USA, 103, 19386-19389, 2006.

Cao, H. L., Huang, Z. L., Zhang, L. Y., and Kong, G. H.: Vegetation Map of Dinghushan Nature Reserve, In Tropical and Subtropical Forest Ecosystem, Vo 19 (ed. Dinghushan Forest Ecosystem Research Station), 1-9, China Environmental Science Press, Beijing, 2002 (in Chinese with English abstract).

Carter, M. R. and Gregorich, E. G. (Eds.): Soil Sampling and Methods of Analysis, 2nd Edn., CRC Press, Taylor \& Francis, Boca Raton, FL., 1224 pp., ISBN 978-0-8493-3586-0, 2008.

Chapin III, F. S., McFarland, J. W., McGuire, A. D., Euskirchen, E. S., Ruess, R. W., and Kielland, K.: The changing global carbon cycle: linking plant-soil carbon dynamics to global consequences, J. Ecol., 97, 840-850, 2009.

Chantigny, M. H., Angers, D. A., Prévost, D., Simard, R. R., and Chalifour, F.-P.: Dynamics of soluble organic C and Cmineralization in cultivated soils with varying $\mathrm{N}$ fertilization, Soil Biol. Biochem., 31, 543-550, 1999.

Clark, C. M. and Tilman, D.: Loss of plant species after chronic low-level nitrogen deposition to prairie grasslands, Nature, 451, 712-715, 2008.

Currie, W. S., Aber, J. D., McDowell, W. H., Boone, R. D., and Magill, A. H.: Vertical transport of dissolved organic $\mathrm{C}$ and $\mathrm{N}$ under long-term $\mathrm{N}$ amendments in pine and hardwood forests, Biogeochemistry, 35, 471-505, 1996.

Cusack, D. F., Torn, M. S., McDowell, W. H., and Silver, W.: The response of heterotrophic activity and carbon cycling to nitrogen additions and warming in two tropical soils, Glob. Change Biol., 16, 2555-2572, 2010.

Corre, M. D., Veldkamp, E., Arnold, J., and Wright, S. J.: Impact of elevated $\mathrm{N}$ input on soil $\mathrm{N}$ cycling and losses in lowland and montane forests in Panama, Ecology, 91, 1715-1729, 2010.

de Vries, W., Solberg, S., Dobbertin, M., Sterba, H., Laubhann, D., van Oijen, M., Evans C., Gundersen, P., Kros, J., Wamelink, G. W. W., Reinds, G. J., and Sutton, M. A.: The impact of nitrogen deposition on carbon sequestration by European forests and heathlands, Forest Ecol. Manag., 258, 1814-1823, 2009.

Evans, C. D., Goodale, C. L., Caporn, S. J. M., Dise, N. B., Emmett, B. A., Fernandez, I. J., Field, C. D., Findlay, S. E. G., Lovett, G. M., Meesenburg, H., Moldan, F., and Sheppard, J.: Does elevated nitrogen deposition or ecosystem recovery from acidification drive an increased dissolved organic carbon loss from upland soil? A review of evidence from field nitrogen experiments, Biogeochemistry, 91, 13-35, 2008.

Fang, Y. T., Gundersen, P., Mo, J. M., and Zhu, W. X.: Input and output of dissolved organic and inorganic nitrogen in subtropical forests of South China under high air pollution, Biogeosciences, 5, 339-352, doi:10.5194/bg-5-339-2008, 2008.

Fang, Y., Zhu, W., Gundersen, P., Mo, J., Zhou, G., and Yoh, M.: Large loss of dissolved organic nitrogen in nitrogen-saturated forests in subtropical China, Ecosystems, 12, 33-45, 2009.

Findlay, S. E. G.: Increased carbon transport in the Hudson River: unexpected consequence of nitrogen deposition?, Front Ecol. Environ., 3, 133-137, 2005.

Galloway, J. N., Dentener, F. J., Capone, D. G., Boyer, E. W., Howarth, R. W., Seitzinger, S. P., Asner, G. P., Cleveland, C., Green, P., Holland, E., Karl, D. M., Michaels, A. F., Porter, J. H., Townsend, A., and Vörösmarty, C.: Nitrogen cycles: past, present, and future, Biogeochemistry, 70, 153-226, 2004.

Gilliam, F. S. and Adams, M. B.: Effects of nitrogen on temporal and spatial patterns of nitrate in streams and soil solution of a central hardwood forest, ISRN Ecology, Article ID 138487, doi:10.5402/2011/138487, 2011

Guggenberger, G.: Acidification effects on dissolved organic matter mobility in spruce forest ecosystems, Environ. Int., 20, 31-41, 1994.

Gundersen, P., Emmett, B. A., Kjønaas, O. J., Koopmans, C. J., and Tietema, A.: Impact of nitrogen deposition on nitrogen cycling in forest: a synthesis of NITREX data, Forest Ecol. Manag., 101, 37-55, 1998.

Hagedorn, F., Blaser, P., and Siegwolf, R.: Elevated atmospheric $\mathrm{CO}_{2}$ and increased $\mathrm{N}$ deposition effects on dissolved organic carbon- clues from $\delta^{13} \mathrm{C}$ signature, Soil Biol. Biochem., 34, 355366, 2002.

Hedin, L. O., Brookshire, E. N. J., Menge, D. N. L., and Barron, A. R.: The nitrogen paradox in tropical forest ecosystems, Annu. Rev. Ecol. Evol. Syst., 40, 613-635, 2009.

Huang, W. Z. and Schoenau, J. J.: Fluxes of water-soluble nitrogen and phosphorous in the forest floor and surface mineral soil of a boreal aspen stand, Geoderma, 81, 251-264, 1998.

Huang, Z. F. and Fan, Z. G.: The climate of Dinghushan (in Chinese with English abstract), in: Tropical and Subtropical Forest Ecosystem, vol. 1, 11-23, Science Press, Beijing, 1982.

Huang, Z. L., Ding, M. M., Zhang, Z. P., and Yi, W. M.: The hydrological processes and nitrogen dynamics in a monsoon evergreen broad-leafed forest of Dinghushan, Acta Phytoecol. Sin., 18, 194-199, 1994 (in Chinese with English abstract).

Hyvönen, R., Persson, T., Andersson, S., Olsso, B., Ågren, G. I., and Linde S.: Impact of long-term nitrogen addition on carbon stocks in trees and soils in northern Europe, Biogeochemistry, 89, 121-137, 2008.

Kalbitz, K., Solinger, S., Park, J. H., Michalzik, B., and Matzner, E.: Controls on the dynamics of dissolved organic matter in soils: a review, Soil Sci., 165, 277-304, 2000.

Kaiser, K. and Guggenberger, G.: The role of DOM sorption to mineral surfaces in the preservation of organic matter in soils, Org. Geochem, 31, 711-725, 2000.

Kindler, R., Siemens, J., Kaiser, K., Walmsley, D. C., Bernhofer, C., Buchmann, N., Cellier, P., Eugster, W., Gleixner, G., Gru nwald, T., Heim, A., Ibrom, A., Jones, S. K., Jones, M., Klumpp, K., Kutsch, W., Larsen, K. S., Lehuger, S., Loubet, B., Mckenzie, R., Moors, E., Osborne, B., Pilegaard, K., Rebmann, C., Saunders, M., Schmidt, M. W. I., Schrumpf, M., Seyfferth, J., Skiba, U., Soussana, J.-F., Sutton, M. A., Tefs, C., Vowinckel, B., Zeeman, M. J., and Kaupenjohann, M: Dissolved carbon leaching from soil is a crucial component of the net ecosystem carbon balance, Glob. Change Biol., 17, 1167-1185, 2011.

Knorr, M., Frey, S. D., and Curtis, P. S.: Nitrogen additions and litter decomposition: a meta-analysis, Ecology, 86, 3252-3257, 2005. 
Lal, R.: Forest soils and carbon sequestration, Forest Ecol. Manag., 220, 242-258, 2005.

LeBauer, D. S. and Treseder, K. K.: Nitrogen limitation of net primary productivity in terrestrial ecosystems is globally distributed, Ecology, 89, 371-379, 2008.

Liao, L. Y., Ding, M. M., Zhang, Z. P., Yi, W. M., Guo, G. Z., and Huang, Z. L.: Root biomass and its nitrogen dynamic of some communities in Dinghushan, Acta Phytoecol. Geobot. Sin., 17, 56-60, 1993 (in Chinese with English abstract).

Liu, G. S., Jiang, N. H., and Zhang, L. D.: Soil physical and chemical analysis and description of soil profiles, Beijing, Standards Press of China, 1996.

Liu, L. and Greaver, T. L.: A global perspective on below-ground carbon dynamics under nitrogen enrichment, Ecol. Lett., 13, 819-828, 2010.

Liu, X., Duan, L., Mo, J., Du, E., Shen, J., Lu, X., Zhang, Y., Zhou, X., He, C., and Zhang, F.: Nitrogen deposition and its ecological impact in China: An overview, Environ. Pollut., 159, 2251-2264, 2011.

Lu, X., Mo, J., Gilliam, F. S., Zhou, G., and Fang, Y.: Effects of experimental nitrogen additions on plant diversity in an old-growth tropical forest, Glob. Change Biol., 16, 2688-2700, 2010.

Lü, C. and Tian, H.: Spatial and temporal patterns of nitrogen deposition in China: Synthesis of observational data, J. Geophys. Res., 112, D22S05, doi:10.1029/2006JD007990, 2007.

Luyssaert, S., Schulze, E.-D., Börner, A., Knohl, A., Hessenmöller, D., Law, B. E., Ciais, P., and Grace, J.: Old-growth forests as global carbon sinks, Nature, 455, 213-215, 2008.

Magill, A. H. and Aber, J. D.: Dissolved organic carbon and nitrogen relationships in forest litter as affected by nitrogen deposition, Soil Biol. Biochem., 32, 603-613, 2000.

Magill, A. H., Aber, J. D., Currie, W. S., Nadelhoffer, K. J., Martin, M. E., McDowell, W. H., Melillo, J. M., and Steudler, P.: Ecosystem response to 15 years of chronic nitrogen additions at the Harvard Forest LTER, Massachusetts, USA, Forest Ecol. Manag., 196, 7-28, 2004.

Martinelli, L. A., Piccolo, M. C., Townsend, A. R., Vitousek, P. M., Cuevas, E., McDowell, W., Robertson, G. P., Santos, O. C., and Treseder, K.: Nitrogen stable isotopic composition of leaves and soil: tropical versus temperate forests, Biogeochemistry, 46, 4565, 1999.

Matson, P. A., McDowell, W. H., Townsend, A. R., and Vitousek, P. M.: The globalization of nitrogen deposition: ecosystem consequences in tropical environments, Biogeochemistry, 46, 67-83, 1999.

McDowell, W. H., Currie, W. S., Aber, J. D., and Yano, Y.: Effects of chronic nitrogen amendment on production of dissolved organic carbon and nitrogen in forest soils, Water Air Soil Pollut., 105, 175-182, 1998.

McDowell, W. H., Magill, A. H., Aitkenhead-Peterson, J. A., Aber, J. D., Merriam, J. L., and Kaushal, S. S.: Effects of chronic nitrogen amendment on dissolved organic matter and inorganic nitrogen in soil solution, Forest Ecol. Manag., 196, 29-41, 2004.

Michalzik, B., Kalbitz, K., Park, J. H., Solinger, S., and Matzner, E.: Fluxes and concentrations of dissolved organic carbon and nitrogen - a synthesis for temperate forests, Biogeochemistry, 52, 173-205, 2001.

Michel, K., Matzner, E., Dignac, M. F., and Kögel-Knabner, I.: Properties of dissolved organic matter related to soil organic mat- ter quality and nitrogen additions in Norway spruce forest floors, Geoderma, 130, 250-264, 2006.

Mo, J. M., Brown, S., Xue, J. H., Fang, Y., and Li, Z.: Response of litter decomposition to simulated $\mathrm{N}$ deposition in disturbed, rehabilitated and mature forests in subtropical China, Plant Soil, 282, 135-151, 2006.

Mo, J. M., Zhang, W., Zhu, W., Gundersen, P., Fang, F., Li, D., and Wang, H.: Nitrogen addition reduces soil respiration in a mature tropical forest in southern China, Glob. Change Biol., 14, 403412, 2008.

Monteith, D. T., Stoddard, J. L., Evans, C. D., de Wit, H. A., Forsius, M., Høgåsen, T., Wilander, A., Skjelkvåle, B. L., Jeffries, D. S., Vuorenmaa, J., Keller, B., Kopácek, J., and Vesely, J.: Dissolved organic carbon trends resulting from changes in atmospheric deposition chemistry, Nature, 450, 537-540, 2007.

Moore, T. R., Desouza, W., and Koprivnijak, J. F.: Controls on the sorption of dissolved organic carbon in soils, Soil Sci., 154, 120 129, 1992.

Nadelhoffer, K. J., Emmett, B. A., Gundersen, P., Kjonaas, O. J., Koopmans, C. J., Schleppi, P., Tietema, A., and Wright, R. F.: Nitrogen deposition makes a minor contribution to carbon sequestration in temperate forests, Nature, 398, 145-148, 1999.

Neff, J. C. and Asner, G. P.: Dissolved organic carbon in terrestrial ecosystems: Synthesis and a model, Ecosystems, 4, 29-48, 2001.

Ouyang, X., Zhou, G., Huang, Z., Zhou, C., Li, J., Shi, J., and Zhang, D.: Effect of $\mathrm{N}$ and $\mathrm{P}$ addition on soil organic $\mathrm{C}$ potential mineralization in forest soils in South China, J. Environ. Sci., 20, 1082-1089, 2008.

Park, J. H., Kalbitz, K., and Matzner, E.: Resource control on the production of dissolved organic carbon and nitrogen in a deciduous forest floor, Soil Biol. Biochem., 34, 813-822, 2002.

Phillips, O. L., Malhi, Y., Higuchi, N., Laurance, W. F., Nuñez, P. V., Vasquez, R. M., Laurance, S. G., Ferreira, L. V., Stern, M., Brown, S., and Grace, J.: Changes in the carbon balance of tropical forests: evidence from long-term plots, Science, 282, 439442, 1998.

Post, W. M., Emanuel, W. R., Zinke, P. J., and Stangenberger, A. G.: Soil carbon pools and world life zones, Nature, 298, 156159, 1982.

Pregitzer, K. S., Zak, D. R., Burton, A. J., Ashby, J. A., and MacDonald, N. W.: Chronic nitrate additions dramatically increase the export of carbon and nitrogen from northern hardwood ecosystems, Biogeochemistry, 68, 179-197, 2004.

Qualls, R. G. and Bridgham, S. D.: Mineralization rate of 14Clabeled dissolved organic matter from leaf litter in soils of a weathering chronosequence, Soil Biol. Biochem., 37, 905-916, 2005.

Rappe-George, M. O., Gärdenäs, A. I., and Kleja, D. B.: The impact of four decades of annual nitrogen addition on dissolved organic matter in a boreal forest soil, Biogeosciences, 10, 1365-1377, doi:10.5194/bg-10-1365-2013, 2013.

Schindler, D. W. and Bayley, S. E.: The biosphere as an increasing sink for atmospheric carbon - estimates from increased nitrogen deposition, Global Biogeochem. Cy., 7, 717-733, 1993.

Schwesig, D., Kalbitz, K., and Matzner, E.: Mineralization of dissolved organic carbon in mineral soil solution of two forest soils, J. Plant Nutr. Soil Sci., 166, 585-593, 2003.

Shen, C. D., Liu, D. S., Peng, S. L., Sun, Y. M., Jiang, M. T., Yi, W. X., Xing, C. P., Gao, Q. Z., Li, Z., and Zhou, G. Y.: ${ }^{14}$ C measure- 
ment of forest soils in Dinghushan Biosphere Reserve, Chinese Sci. Bull., 44, 251-256, 1999.

Sinsabaugh, R. L., Zak, D. R., Gallo, M., Lauber, C., and Amonette, R.: Nitrogen deposition and dissolved organic carbon production in northern temperate forests, Soil Biol. Biochem., 36, 1509-1515, 2004.

Sjöberg, G., Bergkvist, B., Berggren, D., and Nilsson, S. I.: Longterm $\mathrm{N}$ addition effects on the $\mathrm{C}$ mineralization and DOC production in mor humus under spruce, Soil Biol. Biochem., 35, 1305-1315, 2003.

Sleutel, S., Vandenbruwane, J., De Schrijver, A., Wuyts, K., Moeskops, B., Verheyen, K., and De Neve, S.: Patterns of dissolved organic carbon and nitrogen fluxes in deciduous and coniferous forests under historic high nitrogen deposition, Biogeosciences, 6, 2743-2758, doi:10.5194/bg-6-2743-2009, 2009.

Smemo, K. A., Zak, D. R., Pregitzer, K. S., and Burton, A. J.: Characteristics of DOC exported from northern hardwood forests receiving chronic experimental $\mathrm{NO}_{3}^{-}$deposition, Ecosystems, 10 , 369-379, 2007.

Thomas, R. Q., Canham, C. D., Weathers, K. C. and Goodale, C. L.: Increased tree carbon storage in response to nitrogen deposition in the US, Nat. Geosci., 3, 13-17, 2010.

Townsend, A., Cleveland, C., Houlton, B., Alden, C., and White, J. W.: Multi-element regulation of the tropical forest carbon cycle, Front. Ecol. Environ., 9, 9-17, 2011.

Van den Berg, L. J., Peters, C. J., Ashmore, M. R., and Roelofs, J. G.: Reduced nitrogen has a greater effect than oxidised nitrogen on dry heathland vegetation, Environ. Pollut., 154, 359-369, 2008 .
Vitousek, P. M. and Howarth, R. W.: Nitrogen limitation on land and in the sea. How can it occur?, Biogeochemistry, 13, 87-115, 1991.

Vitousek, P. M. and Sanford, R. L.: Nutrient cycling in moist tropical forest, Annu. Rev. Ecol. Syst., 17, 137-167, 1986.

Wen, D. Z., Wei, P., Kong, G. H., and Ye, W. H.: Production and turnover rate of fine roots in two lower subtropical forest sites at Dinghushan, Acta Phytoecol, Sin,, 23, 361-369, 1999 (in Chinese with English abstract).

Wright, S. J., Yavitt J. B., Wurzburger, N., Turner, B. L., Tanner, E. V., Sayer, E. J., Santiago, L. S., Kaspari, M., Hedin, L. O., Harms, K. E., Garcia, M. N., and Corre, M. D.: Potassium, phosphorus or nitrogen limit root allocation, tree growth and litter production in a lowland tropical forest, Ecology, 92, 1616-1625, 2011.

Yano, Y., McDowell, W. H., and Aber, J. D.: Biodegradable dissolved organic carbon in forest soil solution and effects of chronic nitrogen deposition, Soil Biol. Biochem., 32, 17431751, 2000.

Zak, D. R., Holmes, W. E., Burton, A. J., Pregitzer, K. S., and Talhelm, A. F.: Simulated atmospheric $\mathrm{NO}_{3}^{-}$deposition increases soil organic matter by slowing decomposition, Ecol. Appl., 18, 2016-2027, 2008.

Zhou, G. Y. and Yan, J. H.: The influences of regional atmospheric precipitation characteristics and its element inputs on the existence and development of Dinghushan forest ecosystems, Acta Ecol. Sin., 21, 2002-2012, 2001 (in Chinese with English abstract).

Zhou, G. Y., Liu, S. G., Li, Z. A., Zhang, D. Q., Tang, X. L., Zhou, C. Y., Yan, J. H., and Mo, J. M.: Old-growth forests can accumulate carbon in soils, Science, 314, 1417, doi:10.1126/science.1130168, 2006. 